\title{
Peace in International Relations
}

\section{Cornelia Beyer}

While the daily news can give us an impression that we are constantly in a state of war, most of the world at most days in the year is in fact peaceful, if we apply a minimal definition of peace, meaning the absence of violence. Peace, in a way, is more the norm in international relations than is war.

This fact goes strangely unnoticed in the discussion about war and peace. Most researchers focus at the times when things go wrong, and violence and wars occur. While this is reasonable, as we want to understand the causes of conflict, so we need to look at conflict, it might give a wrong impression and prevent thinking about peace, what constitutes it and how to improve it.

As Werner Levi writes:

A mentality prevails which tends to neglect the possibility that wars may result, not from factors present in a war situation, but from the absence of factors safeguarding peace. The unpopularity of tackling the problem of this assumption is explicable. First of all, the drama of war attracts attention; it stimulates thoughts about its avoidance. Second, it is considerably more difficult to look for conditions absent in war - in view of the illimitable number of conditions which have to be present to preserve peace - and then show that the absence of any of them is responsible for the outbreak of war.

Hence, similar to the understanding of Galtung when he wrote about positive peace, Levi maintains that we need to understand the conditions of peace in order to create it. It will not 
suffice to understand the conditions of war in order to prevent it. We need to know what we are working towards. We need to understand and know what we want to achieve.

If we follow the thought of Galtung, we need to progress from thinking in the arguably still too narrow lines of IR when thinking about peace. We need to broaden our understanding of peace, to include more of its conditions, to be able to reflect on possible ways to progress to this overall goal. We need to deepen and widen our conception of peace.

First to mention is that we need to deepen our understanding of peace. Issues to think about here are welfare, the reduction of inequality and poverty, the promotion of health etc. Inequality, in particular, has experienced a recent revived interest as a condition that is conducive to war. While it is a factor contributing to violence within states, even democracies, it is also a factor contributing to violence in the international world, both within states that failed or a not democratic, as well as between states and between states and other entities. Other factors, such as health and mental health, for example, are just recently been brought into the discussion in International Relations, and their connection to peace and war is not yet fully understood. It is clear, though, that poor physical and mental health is related to reduced life expectancy and is caused in part by poverty and deprivation, but also by other stressors, such as the experience of conflict and trauma. It is a also suspected that poor mental health in any one country might be a precursor for violence in that country. Gender relations, finally, are also to consider when thinking about peace. A society in which women are oppressed should not count as a peaceful society. Likewise, a society in which other minorities are oppressed or discriminated upon should not count as such.

Overall, this means we need to deepen our understanding of peace. But how can we conceptualise a peace that is more conducive to these matters? A point to think of here is human rights and civil rights, and overall social justice as a catch all term to comprise these. Social justice, however, might be easier to achieve in a single society, rather than on a global level. This holds in particular as long 
as we distinguish between states and nations. While, for example, the United States did more than their share to promote human rights in the world, as long as the world is divided in quarrelling states, this might not be achievable. States will guard their sovereign rights, and social justice will remain under the jurisdiction of any one state, and hence we might not be able to ensure it. This leads me to the second point: We need to broaden the scope of our conception of peace.

So second, we have to broaden our understanding of peace. As Werner Levi maintains in his much ignored writings on the causes of peace, the fundamental conditions that are lacking are the missing integration of peoples into one common global body as well as the lack of one common purpose.

Levi describes this as the difference between the international area, where he, like the realists, finds something like anarchy to persist, meaning pure politics, the struggle for power, and self-help. While his description of the international area is not semantically aligned with Realist thought, he resembles in his description very much the ideas that Waltz proposed much later in Theory of International Politics. For him, the lack of integration of the peoples in the international arena with one common goal and into one common unity is the main cause for the persistence of war. While he does not openly call for this, though, the cause for peace, similar to the causes for peace at the national level, would be integration internationally into one common body politic with one common 'end'.

This thinking preceded some of the discussions outside the Democratic Peace Theory discourse that focus on the conditions of peace in today's world. For example, currently, the discussion about global integration into a world state is revived. Many authors maintain the need for politically integrating the nations into one body politic, with some common governance structures above them.

While some proposals of the existing international institutions are made, the most persistent idea is the creation of a global parliament, similar to the European parliament, in which the global populace could form its political will and enact global democracy. 
The argument is that it would be impossible to provide for conditions for peace, such as welfare and human rights and the absence of violence, for example, without the global integration of the nations.

The above leads to the conclusion that thinking about Democratic Peace and the absence of violence might not be sufficient when thinking about peace. We need, as stated above, to think how we can deepen and broaden our understanding of peace.

Critics might argue that this leads necessarily to utopian thinking. And utopias have brought much harm to the world. Creating peace often leads to more conflict, as for example seen with the application of the Democratic Peace idea to cases of Afghanistan and Iraq, or if we consider the post-World War II order a cause for the Cold War to emerge.

Utopias can however be misused to create a world of harm and destruction, as well as used to create more peace and harmony in the world. Nazi Germany was arguably a case for the former, while with the creation of the European Union we see a case of the latter. What seems to be important when following the utopian thinking, is to take gradual approaches at realising any utopia. A step by step approach was followed with the creation of the European Union, where spill over processes led to a harmonious growing-together of Europe after the Second World War.

What, however, distinguishes a harmful from a positive utopia?

Galtung already mentioned in his above cited Editorial the idea of integration. Integration is a mainstay of peace research, and has found its most famous expression arguably with the ideas of Mitrany and other theorists on European integration. Indeed, if we look at Social Psychology, this research indicates that a lack of integration and the formation of distinct groups are at the root of most conflicts. As soon as groups form, it has been found in Social Psychology, discrimination and conflicts start to occur. Group formation, to some, is the primary root cause of conflict 
formation. And group formation can be connected to the cause of war in international relations when thinking about nationalism and racism, as examples. Group formation is found as an explanation for both war and stability in Realism with the balance of power mechanism. Group formation is less accepted in Liberal thought, where integration into common organisations is thought to be more important and where ideas about interdependence transcend the logic of group formation. The idea in Liberalism is that we need to overcome the focus on the state, nationalism, and self-help resulting from an obsession with sovereignty. However, this still needs to be balanced with a certain amount of freedom.

Peace Psychology goes further than that and looks into group formation at the substate level. It analyses discrimination and oppression of various minorities and how they can be overcome. We need to broaden the thinking on integration therefore to include the substate level, to expand our thinking how group formation and resulting discrimination can be overcome not only between states but also within societies.

In Buddhism, for example, where compassion is the tool to apply to achieve peace, it needs to be applied to all living things, all humans, either rich or poor, male or female, healthy or unwell, and including all living things, animals and nature. For us, this implies a thinking about further broadening our concept of peace, and finally utopia, to include aspects of human security, environmental security and animal welfare, for example.

Human security is a concept that has been brought forward by authors such as Ken Booth, who argued that the individual should be the focus of our thinking on security, rather than the state. New threats to security and transnational processes, such as climate change and terrorism, pose risks less to the survival of individual states and more to the survival of individuals. For this reason, we need to broaden our concepts of security to include these individuals that are threatened. But we must not stop with individuals. We need to expand out conception of peace towards an ecological conception that includes life on earth. 
Furthermore, we must not solely think of security, but rather broaden the concept of security to include additional aspects. Security means the absence of harm to the secured object. The absence of harm equals the minimal definition of peace according to Galtung, a negative peace. We need to include additional aspects when thinking of peace, such as empowerment, freedom, rights, etc.

As Oliver Richmond writes in The Transformation of Peace, pacifism has not gained much attention in the International Relations literature. There is a stark silence about pacifist ideas in this literature indeed, and even the most prominent peace researcher, Johan Galtung, shied away from fully supporting pacifism when he looked at Buddhist ideas for peace and maintained that these were enabling oppression.

However, it is a shame that he came to this conclusion. Finally, all things considered, there is no abolition of war as long as pacifism does not hold more prominence in the global culture. Arms reductions will not be agreed upon, disarmament remains unachievable, and all schemes for a peaceful world cannot be realised as long as pacifism does not become the dominant ideology.

Pacifism, which is an essential part of Buddhism again, does not imply statism or the acceptance of any constitution of society. This has been most remarkably shown with the life of Ghandi, who applied pacifist strategies in his struggle to free India from colonial rule. Pacifism allows for change, and for political action, but it rejects violence to achieve any of its goals.

A peaceful world, all other things being necessary but not sufficient conditions, will only be achieved if the leading states take over an ideology of pacifism and spread this ideology via peaceful means on the globe. Practically, for resolving existing conflicts, this means to devise new methods for conflict resolution. Some are already thought about, others will need to be invented. Peaceful change from below, free and fair trade, political integration, intelligence, aid as a conflict prevention strategy, a stop of arms sales, medical approaches etc. have been mentioned in the 
literature already. Many more can be devised and are necessary for enabling a transition towards a peaceful world.

Without pacifist conflict resolution strategies, the world will never reach a state where peace as the minimum definition of the absence of violence prevails.

Alexander Wendt has just recently prevented an application of quantum physics to social relations. According to quantum physics, the nature of reality does not comply with our materialistic worldview and the distinction between energy and matter does not hold. This is in line with the interpretation of many spiritual traditions, in particular from the East, who claim that all is energy and all is connected.

This implies that every individual has a responsibility to promote peace, and peace can and should be created at all levels and by all people combined. Buddhist thinking understands this when it claims that peace starts with the actions of each and every one and when it calls for a perfection of the self.

I will in the following present some ideas on the individual responsibilities for peace, and then go on to look what should be done at the societal level and what at the systemic level.

One the one hand, individuals first and foremost need to be empowered to pursue a path of peace. This means this realisation of human rights, such as security, welfare and political rights. Without the presence of individual empowerment, peace might not spring from the individual.

On the other hand, it should be an individual duty to pursue the path of peace. In most states, this is realised at a basic level with the prohibition of the use of individual violence as well as increasingly with the prohibition on discrimination and other oppressive behaviours. Many other peace promoting behaviours can be thought about. Some are increasingly taken up by Western people, such as vegetarianism, which has become a fad in many Western societies and which is an 
essential part in many Eastern societies as it is thought to be a part of a compassionate lifestyle. If we allow animals to be killed for our consumption, the argument goes, we are not engaging in universal compassion and the step to harming other people is not that far.

Within societies, education and social justice again are probably the most effective tool to support the development of peaceful individuals, communities and the state in general. While the monopoly of force, the law and the police are needed to act as deterrents against negative behaviours of all sorts, these are negative tools, and they only can serve to prevent and restrict one kind of behaviour. They do not in themselves serve for creating positive behaviour, integration and harmony. For the latter, education and social justice are the most applicable tools. Education, however, needs to be accessible to the broadest range of individuals possible. In addition to education, the state fulfils and important function by ensuring the welfare of its citizens, and determining the laws that any society is governed by. These can be detrimental to peace, such as gun laws in the US, or conducive to peace, such as sexual consent laws recently introduced.

At the level of the international system, we have to think about major transformations also. We have to transform the international system into one that is more integrated, more democratic and more conducive to human rights, as well as other rights mentioned above. This would initially mean a strengthening of the international institutions, with the final goal of the creation of a world state, and a democratisation thereof. Integration could for example mean to expand NATO to include states that are outside its reach, such as Russia. A revised function of NATO, more in line with peacekeeping forces of the UN, would need to be implemented. Democratisation would necessitate a world parliament, which would need to be elected by the global populace. This world parliament would necessitate a somewhat integrated global demos. Peoples in the world would need to have a global orientation to allow for global democracy to work. This would be facilitated if globally social justice would be ensured and poverty reduced by a global welfare state and crises would be prevented by an early warning system for war based on mental health data. We would 
This is an Accepted Manuscript of an article published by Taylor \& Francis in Peace Review on 12 Feb 2018, available online: http://www.tandfonline.com/10.1080/10402659.2017.1418704

need some basic cosmopolitan identities. This could be facilitated with the spread of the internet and working towards connecting individuals around the globe more with this tool. These ideas are just some ideas for the promotion of peace. More, of course will be needed.

Suggested readings:

Beyer, Anna Cornelia. 2016. International Political Psychology. Explorations into a New Discipline. London: Palgrave.

Dalai Lama. 1999. The Art of Happiness: A Handbook for the Living. Sydney: Hodder Paperbacks.

Galtung, Johan. 1964. "Editorial”. Journal of Peace Research, 1:1, 1+4.

Galtung, Johan. 1985. Peace and Buddhism. Available at:

$<$ https://www.transcend.org/galtung/papers/Peace $\% 20$ and $\% 20$ Buddhism.pdf $>$, last accessed on 24.03.2017.

Kant, Immanuel. 1795. Perpetual Peace. London: Swan Sonnenschein.

Levi, Werner. 1960. "On the Causes of War and the Conditions of Peace". The Journal of Conflict Resolution, 4:4, 411-420.

Levi, Werner. 1964. “On the Causes of Peace”. The Journal of Conflict Resolution, 8:1, 23-35.

Levi, Werner. 1965. “The Concept of Integration in Research on Peace”. Background, 9:2, 111-126. Mitrany, David. 1966. A Working Peace System. Chicago: Quadrangle Books.

Oneal, John R., Russett, Bruce and Michael L. Berbaum. 2003. "Causes of Peace: Democracy, Interdependence, and International Organizations, 1885-1992”. International Studies Quarterly, 47, 371-393.

Richmond, O.P. 2006. "The problem of peace: Understanding the "liberal peace”. Conflict, Security \& Development, October, 291 - 314.

Richmond, Oliver. 2007. The Transformation of Peace. Basingstoke: Palgrave. 
This is an Accepted Manuscript of an article published by Taylor \& Francis in Peace Review on 12 Feb 2018, available online: http://www.tandfonline.com/10.1080/10402659.2017.1418704.

Todenhoefer, Juergen. 2015. I know ISIS fighters. Western bombs on Raqqa will fill them with joy. Available at: $\quad$ <http://www.theguardian.com/commentisfree/2015/nov/27/bomb-isis-west-learnednothign-from-war-terror-defeat-muslim-world-equal-partner>, last accessed 24.03.2017. 